\title{
Congenital Pulmonary Valve Insufficiency
}

National Cancer Institute

\section{Source}

National Cancer Institute. Congenital Pulmonary Valve Insufficiency. NCI Thesaurus. Code C103935.

Dysfunction of the pulmonary valve characterized by incomplete valve closure that is present at birth. 